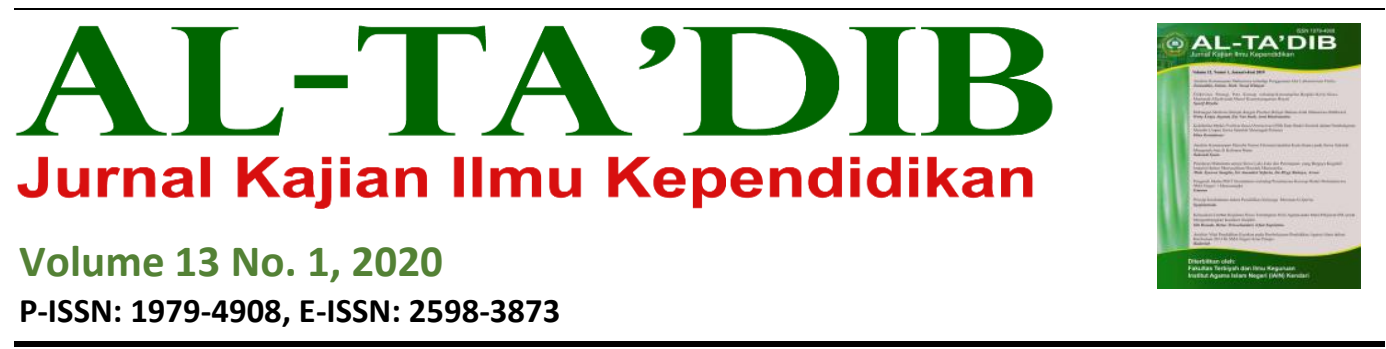

\title{
Analisis Perbandingan Karakter Menghargai Prestasi Siswa Sekolah Menengah Atas
}

\section{Arif Rahman Hakim ${ }^{1}$}

${ }^{1}$ Universitas Jambi, Indonesia. E-mail: hakimarifrahman15@gmail.com

\begin{tabular}{l} 
INFORMASI ARTIKEL \\
\hline Kata Kunci: \\
Karakter; menghargai; \\
prestasi; siswa sekolah \\
menengah atas; survei \\
Cara Mensitasi: \\
Hakim, M. A. R. (2020). \\
Analisis perbandingan \\
karakter menghargai \\
prestasi siswa sekolah \\
menengah atas. Al-Ta'dib: \\
Jurnal Kajian Ilmu \\
Kependidikan, 13(1), 57- \\
64. \\
DOI:
\end{tabular}

\begin{abstract}
ABSTRAK
Penelitian survei ini bertujuan untuk untuk mengetahui bagaimana perbandingan sikap siswa sekolah menengah atas terhadap pendidikan karakter menghargai prestasi. Survei yang menggunakan metode komparatif ini dilaksanakan pada 890 siswa sebagai populasi. Sampel yang digunakan dalam penelitian ini sebanyak 58 siswa kelas XII IPA di salah satu sekolah menengah atas. Hasil penelitian menunjukkan bahwa siswa yang berpartisipasi dalam penelitian ini memiliki karakter yang baik dalam menghargai prestasi. Mengingat pentingnya penerapan pendidikan karakter pada siswa pada setiap jenjang pendidikan, sangat diharapkan adanya peningkatan kesadaran siswa dalam menghargai prestasi.
\end{abstract}




\begin{tabular}{l} 
ARTICLE INFO \\
\hline Keywords: \\
Achievement; \\
appreciation; character; \\
comparative; high school \\
student; survey \\
How to cite: \\
Hakim, M. A. R. (2020). \\
Analisis perbandingan \\
karakter menghargai \\
prestasi siswa sekolah \\
menengah atas. Al-Ta'dib: \\
Jurnal Kajian Ilmu \\
Kependidikan, 13(1), 57- \\
64. \\
DOI:
\end{tabular}

\begin{abstract}
This survey study aims to examine the high school students attitude against the character education values achievement. The comparative survey was administered to a population of 890 students. The sample comprises of 58 students at a high school. Results of the study showed that the students indicate good character in valuing achievement. Due to the importance of the application of character education to students at every level of education, it is desirable to have an increase in student awareness in valuing achievement.
\end{abstract}

\section{Pendahuluan}

Penelitian mengenai pendidikan karakter di sekolah telah menjadi pusat perhatian para akademisi maupun peneliti beberapa tahun terakhir (Fauzi, Zainuddin, \& Ayok, 2017; Febrianshari \& Ekowati, 2018). Pendidikan karakter adalah sesuatu yang mendasar dalam proses pendidikan manusia, bukan pendidikan yang bersifat tambahan karena setiap proses pendidikan harus didasarkan pada pendidikan karakter. Pengembangan pendidikan karakter adalah suatu peluang bagi penyempurnaan jati diri siswa melalui berbagai macam keterampilan. Kondisi pembelajaran berbasis pendidikan karakter merupakan usaha untuk menjadikan pembelajar sebagai siswa yang memiliki keutamaan, keseimbangan akademik dan moral (Al Musafiri, 2017).

Listyono (2012) mengemukakan bahwa karakter bermakna menandai dan memfokuskan bagaimana mengaplikasikan nilai kebaikan dalam bentuk tindakan atau tingkah laku, sehingga orang yang tidak jujur, kejam, rakus dan perilaku jelek lainnya dikatakan sebagai orang berkarakter jelek. Sebaliknya, orang yang perilakunya sesuai dengan kaidah moral disebut orang berkarakter mulia. Kurniawati dan Irsyadillah (2018) menjelaskan bahwa karakter merupakan perwatakan yang muncul yang membedakan orang lain yang tergambar dan tertanam dalam diri seseorang yang akan nampak pada saat seseorang berperilaku dalam kehidupan keseharian. Karakter akan muncul memperkuat kompetensi seseorang sehingga ia tidak bisa diharapkan muncul secara cepat dan instan. Karakter perlu pembiasaan yang nantinya akan 
terakumulasi dalam kompetensi dan nampak dalam perilaku kehidupan sehingga adanya perencanaan dan program dalam pembentukan karakter.

Untuk mengantisipasi pengikisan karakter peserta didik, Fauzi, dkk. (2017) melakukan penelitian melalui pemetaan menggunakan angket untuk mengetahui kedalaman karakter peserta didik, mengarahkan pengajar yang telah berpengalaman, memberikan sumber belajar yang jelas, dan memberikan tindakan pembelajaran seperti strategi pembelajaran, metode pembelajaran, dan model pembelajaran yang tepat bagi para peserta didik. Dalam penelitian serupa, Febrianshari dan Ekowati (2018) menemukan bahwa penilaian karakter bisa muncul karena sistem pendidikan belum berhasil menciptakan lulusan yang memiliki keunggulan kognitif, psikomotorik, dan afektif. Terkait pendidikan karakter atau pendidikan moral, pemerintah telah memberikan respon positif melalui Kebijakan Nasional Pembangunan Karakter Bangsa yang memuat arah kebijakan, tahapan, dan strategi yang digunakan untuk pembangunan karakter bangsa, khususnya para peserta didik (Amir, 2017).

Menurut Narwanti (2011, dalam Nurjannah, 2017), menghargai prestasi merupakan perilaku dan karakter yang mendorong diri seseorang untuk menghasilkan sesuatu yang berguna bagi masyarakat dan mengakui serta menghormati keberhasilan orang lain. Menghargai prestasi orang lain misalnya bisa dengan cara memberikan tepuk tangan ketika pemenang diumumkan di depan orang banyak. Dengan cara itu, akan terbentuk sikap individu yang mampu menyempurnakan dirinya agar menjadi pribadi yang baik dan berguna bagi nusa, bangsa dan agama. Sejalan dengan pentingnya penanaman karakter pada pembelajar, tujuan penelitian adalah untuk mengetahui perbandingan sikap siswa sekolah menengah atas terhadap pendidikan karakter menghargai prestasi. Penelitian ini perlu dilakukan agar dapat diketahui secara empiris sikap menghargai prestasi siswa di tingkat sekolah menengah atas. Hal ini berimplikasi pada pentingnya menerapkan karakter menghargai prestasi kepada siswa di lingkup sekolah.

\section{Metode Penelitian}

Penelitian survei ini menggunakan metode komparatif. Penelitian dilaksanakan di salah satu sekolah menengah swasta di Kota Jambi, Indonesia dengan populasi keseluruhan dari kelas X hingga kelas XII sejumlah 890 siswa. Sampel yang digunakan dalam penelitian ini, yaitu kelas XII IPA 3 sebanyak 28 siswa dan XII IPA 4 sebanyak 30 siswa. Total 58 siswa sebagai sampel dalam penelitian ini dengan menggunakan populasi sekaligus sebagai sampel penelitian. Setelah data kuisioner yang didistribusikan dari seluruh responden terkumpul, data dianalisis untuk mengetahui perbandingan karakter menghargai prestasi pada siswa. 
Teknik analisis data yang digunakan adalah melakukan uji prasyarat analisis yaitu uji normalitas, dan uji linearitas.

Pengumpulan data dilakukan melalui pemberian angket berisi 25 pernyataan sikap. Semua pernyataan merupakan pernyataan positif. Sikap siswa pada pendidikan karakter menghargai prestasi dalam penelitian ini menggunakan skala Likert. Skala yang digunakan sangat sering (SS), sering (S), kadang-kadang (KK), dan tidak pernah (TP). Setiap item positif dalam instrumen yang memiliki nilai: $\mathrm{SS}=4, \mathrm{~S}=3, \mathrm{KK}=2$, dan $\mathrm{TP}=1$. Setelah itu angket terkumpul kembali, skor peserta didik pada tiap angket diinput ke dalam aplikasi microsoft excel. Data kemudian diolah menggunakan statistik komparatif dengan bantuan software statistik untuk menguji perbandingan. Tujuan dari analisis perbandingan ini yaitu untuk mencari bukti apakah terdapat perbedaan dari satu variabel dengan objek yang berbeda. Selain itu, uji perbandingan dilakukan untuk mengetahui objek mana yang memiliki pendidikan karakter menghargai prestasi lebih baik dari satu variabel tersebut.

\section{Hasil dan Pembahasan}

Analisis data dalam penelitian ini dilakukan dengan menggunakan uji prasyarat dan uji hipotesis. Uji prasyarat yang digunakan adalah uji prasyarat analisis yang meliputi uji normalitas data skor karakter menghargai prestasi siswa dan uji homogenitas data karakter menghargai prestasi siswa. Teknik analisis uji hipotesis yang dilakukan dalam penelitian ini tergantung pada hasil uji prasyarat yang dilakukan. Melalui uji hipotesis, ada atau tidaknya perbedaan karakter menghargai prestasi siswa kelas XII IPA 3 dan kelas XII IPA 4 pada karakter menghargai prestasi dapat diketahui.

\subsection{Hasil Uji Prasyarat}

Teknik analisis yang digunakan yaitu uji normalitas data skor karakter menghargai prestasi uji homogenitas data skor karakter menghargai prestasi, dan uji independent T-test data skor karakter menghargai prestasi. Penghitungan yang dilakuakan dengan aplikasi SPSS.

\section{Uji Normalitas}

Uji normalitas skor angket karakter menghargai prestasi digunakan untuk mengetahui apakah data berdistribusi normal atau tidak dan untuk menentukan jenis pengujian statistik yang digunakan dalam menganalisis data selanjutnya. Uji normalitas dilakukan untuk data skor angket karakter menghargai prestasi dari masing-masing kelas yaitu kelas XII IPA 3 dan kelas XII IPA 4. Uji normalitas data skor angket karakter menghargai prestasi dilakukan dengan 
menggunakan Kolmogorov-Smirnov Test karena jumlah sampel kecil dan bukan data berkelompok. Hipotesis untuk uji normalitas data skor hasil belajar adalah: Ho : sebaran data tidak berbeda dengan kurva normal atau data normal. $\mathrm{Ha}$ : sebaran data berbeda dengan kurva normal atau data tidak normal.

Taraf signifikansi yang digunakan adalah 0,05 dengan tingkat kepercayaan 95\%. Pada Tabel 1, jumlah sampel tiap kelasnya $>20$ orang maka hasil uji dilihat pada tabel Kolmogorov-Smirnov ${ }^{a}$. Sehingga, hasil ujinya untuk kelas XII IPA 3 dan XII IPA 4 masing-masing 0.2. Suatu data berdistribusi normal, apabila hasil uji normalitasnya $>0.05$, karena hasil uji didapat sebesar 0.2 , dan $0.2>0.05$, jadi data angket karakter menghargai prestasi yang diperoleh pada kelas XII IPA 3 dan XII IPA 4 adalah normal.

Tabel 1. Hasil Uji Normalitas Angket

\begin{tabular}{lcccccc}
\hline & \multicolumn{2}{c}{ Kolmogorov-Smirnov $^{\mathrm{a}}$} & \multicolumn{3}{c}{ Shapiro-Wilk } \\
\cline { 2 - 7 } & Statistik & $\mathrm{df}$ & Sig. & Statistik & $\mathrm{df}$ & Sig. \\
\hline Angket & 0,13 & 28 & 0,20 & 0,95 & 28 & 0,21 \\
XII IPA 3 & & & & & & \\
$\begin{array}{l}\text { Angket } \\
\text { XII IPA 4 }\end{array}$ & 0,10 & 28 & 0,20 & 0,98 & 28 & 0,92 \\
\hline
\end{tabular}

\section{Uji Homogenitas}

Analisis yang dilakukan selanjutnya adalah menguji homogenitas data skor angket karakter menghargai prestasi. Uji homogenitas data angket ini dilakukan untuk mengetahui apakah ada kesamaan angket karakter menghargai prestasi kelas XII IPA 3 dan angket karakter menghargai prestasi kelas XII IPA 4. Pengujian homogenitas antara data skor angket karakter menghargai prestasi kelas XII IPA 3 dan kelas XII IPA 4 dilakukan dengan menggunakan Levene's Test. Hipotesis untuk uji homogenitas antara data angket karakter menghargai prestasi kelas XII IPA 3 dan kelas XII IPA 4 ini adalah:

Ho : varian hasil belajar fisika kedua kelas adalah homogen

$\mathrm{Ha}$ : varian hasil belajar fisika kedua kelas adalah tidak

Kriteria pengambilan keputusan dari hasil uji homogenitas antara data angket karakter menghargai prestasi kelas XII IPA 3 dan angket karakter menghargai prestasi kelas XII IPA 4 adalah: Jika harga sig. (2-tailed) Levene's Test $\geq 0,05$, maka Ho atau Ha ditolak. Artinya, tidak ada persebaran varian antara dua data skor angket karakter menghargai prestasi kelas XII IPA 3 dan angket karakter menghargai prestasi kelas XII IPA 4. Dengan kata lain, data skor angket karakter menghargai prestasi kedua kelas tersebut homogen atau kedua kelompok memiliki kemampuan yang sama. Jika harga sig. (2-tailed) Levene's 
Test $<0,05$, maka Ho ditolak atau Ha diterima. Artinya, ada persebaran varian antara data skor angket karakter menghargai prestasi kelas XII IPA 3 dan kelas XII IPA 4. Dengan kata lain, data skor angket karakter menghargai prestasi kedua kelas tersebut adalah homogen atau kedua kelas tersebut memiliki kemampuan yang tidak sama. Hasil penghitungan uji homogenitas antara data angket karakter menghargai prestasi kelas XII IPA 3 dan angket karakter menghargai prestasi kelas XII IPA 4 dengan menggunakan Aplikasi SPSS dipaparkan dalam Tabel 2.

Tabel 2. Hasil Uji Homogenitas Skor Hasil Belajar Fisika kelas XII IPA dan XII IPA 4

\begin{tabular}{rcrrr}
\hline \multicolumn{6}{c}{ Angket } \\
\hline Levene Statistic & df1 & df2 & \multicolumn{2}{l}{ Sig. } \\
\hline 0,042 & 1 & 56 & 0,839 \\
\hline
\end{tabular}

Tabel 2 menunjukkan hasil penghitungan uji homogenitas antara data skor angket karakter menghargai prestasi kelas XII IPA 3 dan XII IPA 4 yang dapat dilihat pada harga signifikansi kolom Levene's Test skor angket karakter menghargai prestasi. Hasil uji homogenitas data skor hasil belajar angket karakter menghargai prestasi menunjukkan harga sig(2-tailed) sebesar 0,839. Nilai $0,839 \geq 0,05$, sehingga dapat disimpulkan bahwa Ho diterima dan Ha ditolak. Hasil tersebut juga dapat dinyatakan bahwa tidak ada perbedaan varian antara angket karakter menghargai prestasi kelas XII IPA 3 dan kelas XII IPA 4.

\subsection{Hasil Uji Hipotesis}

\section{Independent Samples T-test}

Independent Samples T-test skor hasil belajar perlu dilakukan dengan tujuan untuk mengetahui perbedaan rata-rata antara skor angket karakter menghargai prestasi kelas XII IPA 3 dan kelas XII IPA 4. Hipotesis yang digunakan dalam uji Independent Samples T-test untuk kelas XII IPA 3 dan kelas XII IPA 4 adalah: Ho : Tidak ada perbedaan yang signifikan antara rata-rata skor angket karakter menghargai prestasi kelas XII IPA 3 dan kelas XII IPA 4 (Ho: $\mu_{1}=\mu_{2}$ ).

Ha : Ada perbedaan yang signfikan antara rata-rata skor angket karakter menghargai prestasi kedua kelas yaitu kelas XII IPA 3 dan kelas XII IPA 4 (Ho: $\mu_{1} \neq \mu_{2}$ ). 
Tabel 3. Hasil Uji Independent T-test skor karakter menghargai prestasi kelas XII IPA 3 dan kelas XII IPA 4

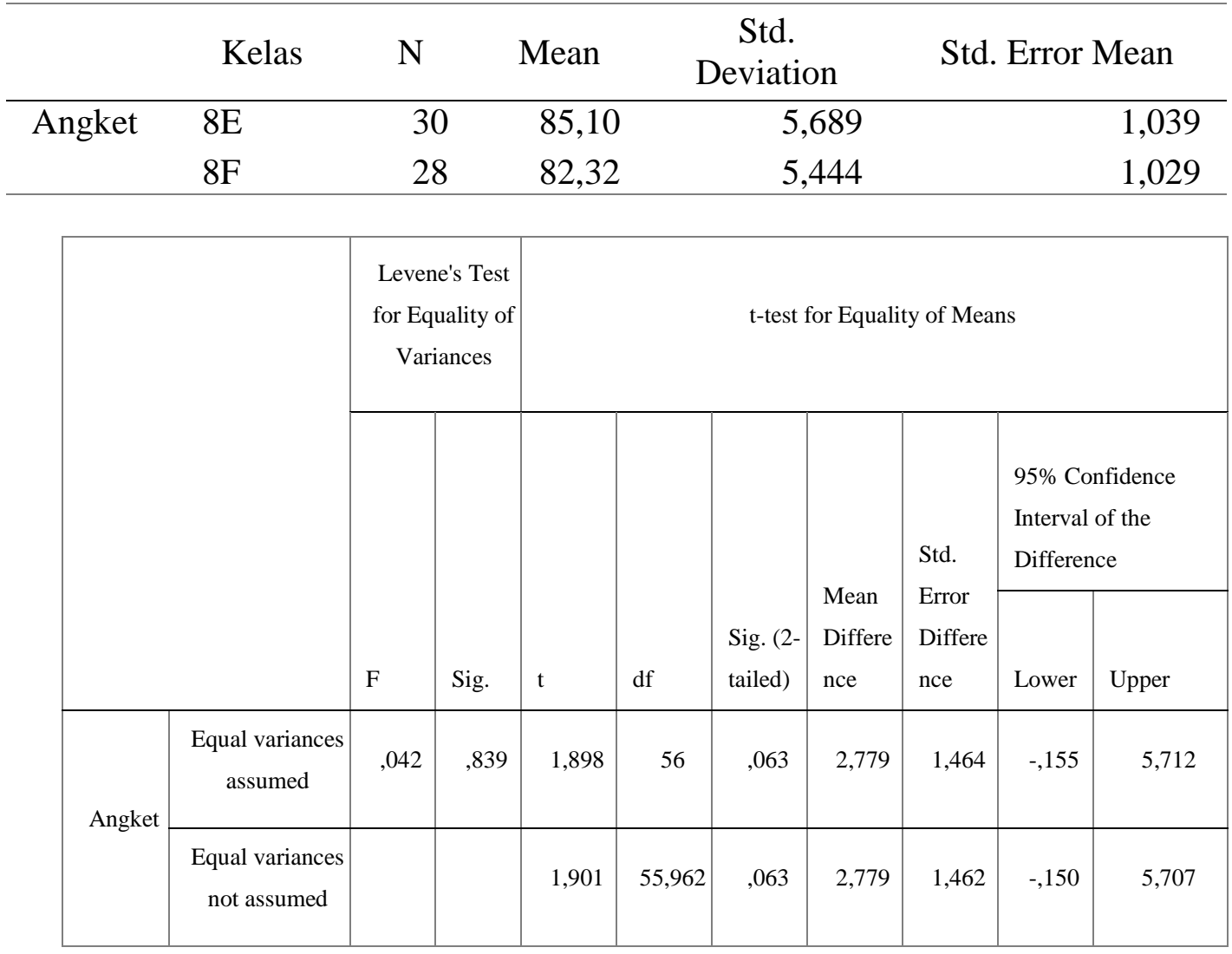

Hasil analisis data di atas menunjukkan bahwa ada perbedaan hasil belajar IPA siswa Kels XII IPA 3 dan kelas XII IPA 4. Penelitian ini menunjukkan bahwa penerapan pendidikan karakter menghargai prestasi dalam sekolah memerlukan dukungan dari berbagai pihak terkait. Dalam dunia pendidikan, kepala sekolah memiliki peran penting untuk mendorong pembentukan pendidikan karakter menghargai prestasi. Selain itu, guru harus menguasai materi yang ada dalam kurikulum pendidikan karakter menghargai prestasi, memadukan dalam mata pelajaran yang terkait, berkoordinasi dengan guru lainnya dan menggunakan metode pembelajaran yang sesuai agar siswa tertarik untuk belajar serta merealisasikannya dalam kehidupan.

\section{Kesimpulan}

Berdasarkan hasil analisis data penelitian dan pengujian hipotesis dapat disimpulkan bahwa dari hasil perhitungan uji hipotesis dengan uji t diperoleh 
$\mathrm{t}_{\text {hitung }}$ lebih kecil dari $\mathrm{t}_{\text {tabel }}$ dan nilai sig (2-tailed) Independent $T$-test adalah 0,063 $\leq 0,05$. Oleh karena itu, Ho ditolak dan Ha diterima. Artinya, ada perbedaan yang signifikan antara rata-rata angket karakter menghargai prestasi kelas XII IPA 3 dan kelas XII IPA 4. Dengan kata lain, hasil uji Independent T-test skor angket karakter menghargai prestasi menujukkan adanya perbedaan yang signifikan antara data angket karakter menghargai prestasi kelas XII IPA 3 dan kelas XII IPA 4. Nilai rata-rata angket karakter menghargai prestasi kelas XII IPA 3 diperoleh sebesar 85,10 dengan Standar Error of Mean 1,039 dan nilai rata-rata hasil belajar kelas XII IPA 4 sebesar 82,32 dengan Standar Error of Mean 1,029.

Penelitian ini berimplikasi pada pentingnya penerapan pendidikan karakter pada siswa di setiap jenjang pendidikan. Oleh karena itu, penelitian ini diharapkan mampu menjadi sumber informasi bagi pengajar dalam upaya meningkatkan kesadaran siswa dalam menghargai prestasi.

\section{Daftar Pustaka}

Al Musafiri, M. R. (2017). Peran kearifan lokal bagi pengembangan pendidikan karakter pada sekolah menengah atas. Jurnal Darussalam: Jurnal Pendidikan, Komunikasi dan Pemikiran Hukum Islam, 8(1), 1-19.

Amir, R. (2017). Membangun karakter dalam perayaan budaya lokal di Kabupaten Takalar. Jurnal Publikasi Pendidikan, 7(3), 127-133.

Fauzi, A. R., Zainuddin., \& Ayok, R. A. (2017). Penguatan karakter rasa ingin tahu dan peduli sosial melalui discovery learning. Jurnal Teori dan Praksis Pembelajaran IPS, 2(2), 27-36.

Febrianshari, D., \& Ekowati, D. W. (2018). Analisis nilai-nilai pendidikan karakter dalam pembuatan Dompet Punch Zaman Now. Jurnal Pemikiran dan Pengembangan Sekolah Dasar (JP2SD), 6(1), 88-95.

Kurniawati, R., \& Irsyadillah. (2018). Analisis nilai karakter dalam teks cerita buku pelajaran siswa sekolah dasar. Master Bahasa, 6(2), 103-114.

Listiyono. (2012). Pendidikan karakter dan pendekatan SETS (Science Environment Technology and Society) dalam perencanaan pembelajaran sains. Jurnal Phenomenon, 2(1), 95-107.

Nurjanah, S. (2017). Penanaman karakter kerja keras dan menghargai prestasi pada siswa. Skripsi tidak dipublikasi. Fakultas Keguruan dan Ilmu Pendidikan, Universitas Muhammadiyah Surakarta. 